\title{
Play On Words on Nurhadi-Aldo Political Memes
}

\author{
Intan Rawit Sapanti ${ }^{1, a)}$ \\ ${ }^{1}$ Indonesian Literature Department, Faculty of Literature, Culture, and Communication, \\ Universitas Ahmad Dahlan, Yogyakarta \\ antanrawit.sapanti@idlitera.uad.ac.id
}

\section{DOI: https://doi.org/10.18196/jkm.111014}

\section{Article Info}

\section{Article history:}

Received 08 March 2019

Revised 15 April 2019

Accepted 07 May 2019

\begin{abstract}
Political satire in the form of Nurhadi-Aldo meme arisingduring the Presidential Election 2019 was one of the reactions towards the massive black or negative campaign happening nowadays. This fictitious couple emerged as a form of refreshment that could entertain the society through its humorous meme. This research aims to explore the wordplay used in Nurhadi-Aldo meme. This research used qualitative research, a study that produces descriptive data, including written or oral words from the subject observed.For collecting data, the research employ observation, consisting of tapping and advanced noting technique, and uninvolved observation conversation technique. The result of this research shows that two language aspects carried out in this meme, namely phonological and semantic aspects support the level of wittiness of the meme. While there are two strategies performed in phonological aspects, namely rime and sound repetition,five strategies are used in semantic aspects, starting from proverb, abbreviation, polysemy, metaphor,to syllogism.
\end{abstract}

Keywords: Meme, Nurhadi-Aldo, Play on Words, Political Satire

\begin{abstract}
ABSTRAK
Satire politik di era menjelang Pilpres 2019 yang muncul dalam bentuk meme Nurhadi-Aldo merupakan salah satu bentuk ekspresi masyarakat yang sudah bosan dengan kampanye hitam atau kampanye negatif. Kemunculan pasangan fiktif dalam bentuk meme ini selain menyindir realitas politik di Indonesia juga bermaksud memberikan penyegaran dan hiburan cerdas terhadap masyarakat Indonesia. Penelitian ini bertujuan untuk menguraikan permainan bahasa yang digunakan dalam penyusunan meme politik Nurhadi-Aldo. Jenis penelitian ini adalah kualitatif sebuah penelitian yang menghasilkan data deskriptif berupa kata-kata tertulis atau lisan dari orang-orang dan perilaku yang dapat diamati. Metode yang digunakan dalam pengumpulan data dilakukan dengan menggunakan metode simak dengan menggunakan teknik sadap dan teknik lanjutan teknik catat dan teknik simak bebas libat cakap. Sedangkan metode analisis data menggunakan metode deskriptif. Hasil dari penelitian ini bahwa terdapat dua aspek kebahasaan yang mendukung kelucuan meme politik NurhadiAldo yaitu aspek fonologis yang menggunakan strategi persamaan bunyi dan pengulangan bunyi serta aspek semantic yang menggunakan strategi peribahasa, singkatan, polisemi, metaphora dan silogisme.
\end{abstract}

Kata kunci : Meme, Nurhadi-Aldo, Permainan Bahasa (Play on Words), Satire Politik 


\section{INTRODUCTION}

The advent of fictional candidate Nurhadi-Aldo (Dildo)appearing in the form of political meme and going viral on Indonesian popular media social (Instagram, Facebook, and Twitter) during the general election in 2019isa manifestation of the mounting reservations of some groups of people who has abhorred the negative campaigns performed by both presidential candidates. The meme mentioned is a type of political satire combining irony and sarcasmto humor. Indonesian political humor consists of several forms, namely: satire, irony, aggressive humor, and self-deprecating humor; and satire itself figures in exposing and criticizing others' mistakes.It is the reason it also has critical functions (Berger, 1997).Nurhadi-Aldo memes compound of pictures, slide photos, and textaimingtorespond tothe current pressing political issue in the social discourses.

"Meme" originally comes from Richard Dawkins concept, in the Selfish Gene (1976), meaning "units of imitations and cultural transmission in the genes." The neologism, then, witnesses a transformation from Dawkins biological concepts to terms pointing out general symptoms of internet meme culture; specifically, a process in which ideas are imitated, spread, and mediated from one person to another through interactions or speech and analog medium or digital one (Brunello, 2012).

Pictures and texts containing in the Nurhadi-Aldo memesare witty and entertaining, and able to prompt the readers to chuckleand even laugh. The comical and unwinding qualities of the memes clearly cannot be detached from their plays on words, or wordplay, as the leading supporter for bumping off the rate of wittiness. Play on words is a deviant use of language that often finds in puns. The phenomenon relates to ambiguity, namely set of words that have similar forms but with different meanings (homonym), or set of words seeing expansions of contexts to have more than one meaning, which is secondary and primary (polysemy).

The wordplay that wasstudied in the research is the role of phonological and semantic aspects occurring in Nurhadi-Aldo memes. For example, in the data number 45, Dildo used a catchy slogan says "Dildo Membangundengan FASTI dan SERIOUS" (Dildo builds certainly and seriously).It carried out a malapropism strategy or mistaken words in a particular established formula with similarsounding words figuring in modifying the previous real meaning (Apte, 1985: 82). FASTI and Serious are puns from a movie title called "Fast and Furious." Taking advantage of the phonological aspects, Dildo succeeded in making unpredictability andcreates humor.

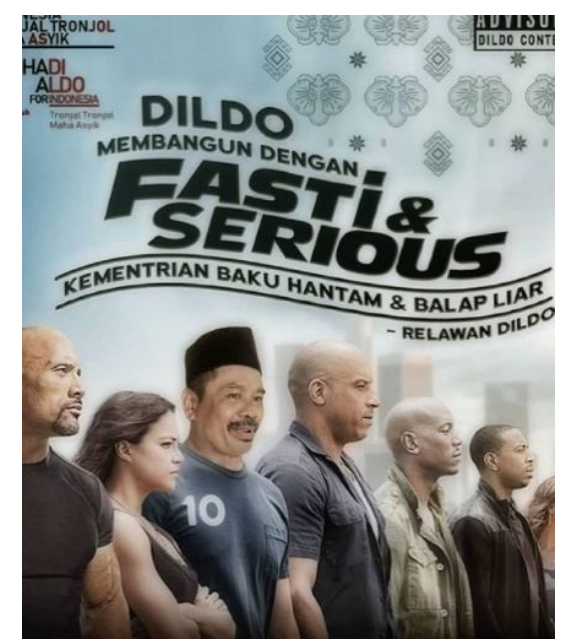

Figure 1. Data 45

Nurhadi-Aldo memesare valuable textsfor linguistic investigation. The research then demonstratedthe linguistic aspect of Nurhadi-Aldo memes, notably its phonological and semantic aspects. 


\section{METHOD}

The research used a qualitative method. Moleong (2005:6) stated that qualitative research is a type of research intending to understanding holistically the experience of research subjects, such as behavior, perceptions, motivations, actions, and so on. The study used thick-description in the form of words and language on specific natural contexts and other relevant scientific tools. As regards qualitative research, Bogdan and Taylor (Moleong, 1998: 3) contended that qualitative methodology is a research procedure resulting descriptive data, including, but not limited to, written and verbal information of observed individuals and the behaviors.

Data collection was conducted using observation, individually, the observation chosen was tapping, advanced recording, and uninvolved observation conversation technique. Observation is chosen for collecting data by listening to the use of language; whether written or oral (Mahsun, 2005:94) Tapping is the primary method observation because observation can only be manifested firstly through tapping. In practice, this method was followed by involved observation conversation, uninvolved observation conversation, noting, and recording.

Since data used in the research were written texts, advanced techniques carried out was a combination between recording technique and unstructured involvement realized in recording some forms of relevant written information. Data used in the research amounted to 70 memes classified into categorized tables based on the linguistic aspects. Another essential process in the study is data analysis, which uses qualitative analysis. Some of the steps are collecting data about Nurhadi-Aldo memes, discriminating the relevant sources, and making conclusions.

\section{ANALYSIS}

The followings are the result of categorizing memes having linguistic aspects. Eight memes contained phonological aspects which six of them providing homonym while two other memes included rhymes. On the other hand, Dildo memes containing semantic aspects were twenty-eight, with six memes using proverbs, eight memes using abbreviations, nine memes using polysemy, three memes using metaphor, and the other two using syllogisms.

Table 1. Linguistic aspects in Dildo memes

\begin{tabular}{llll}
\hline \multirow{2}{*}{ Total } & \multicolumn{2}{l}{ Linguistic aspects } & Total \\
\cline { 2 - 4 } & Phonological & semantic & 6 \\
\hline 6 & Homonym & Proverb & 8 \\
2 & Rhymes & Abbreviations & 9 \\
& & Polysemy & 3 \\
& & Metaphor & 2
\end{tabular}

TOTAL: 34

\section{Phonological aspects supporting Dildo meme wittiness}

Soeparno (2013:60) argued that phonology is a branch of linguistics that studies sound in language and function in differentiating meanings. Phonology is the least or the most basic study in the linguistic hierarchy because its objects study is the last outcome of the particular segmentation process of speech, namely sounds. In the process of making humor, phonological aspect is substantial. The followings were phonological aspects discovered in Nurhadi-Aldo political memes.

\section{Homonym}

The first phonological aspect was homonym. It was found in the following memes, namely data number 5 "McQueen Yaqueen" and data number 55 "Merdeka atau Party." In those two memes, the 
use of malapropism, or wrong words in a specific established formula with similar-sounding words figuring in modifying the previous real meaning, was found (Apte, 1985:182). Data number 5 Mcqueen Yaqueen, which was the main slogan of this fictional candidate, actually was a deviant use of an English cartoon character name (Lightning Mcqueen), but if it were read in Bahasa it would be makin yakin or "becoming more convinced". Likewise, the data number 55 Merdekaatau Party (supposedly "Merdeka atau Mati" or Freedom or death) replaced "mati"(Death) with a party which had similarity in sounds with the standard expression although the meaning is entirely different.

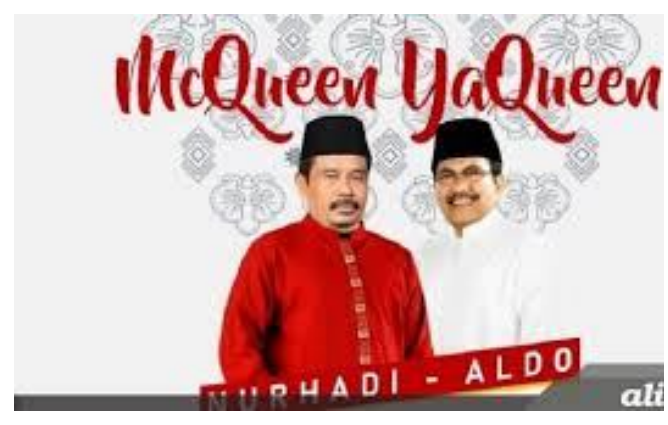

Figure 2. Data 5

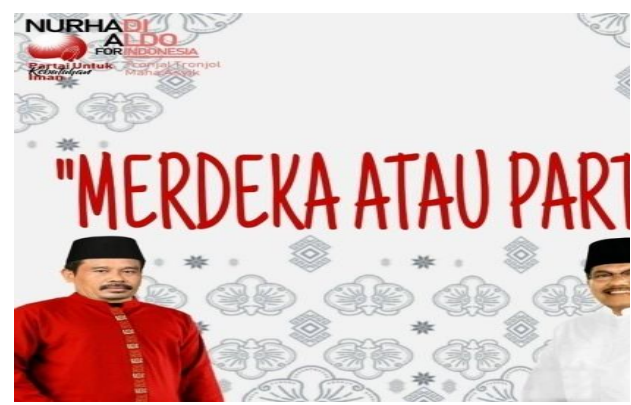

Figure 3. Data 55

Poetic sound repetition

The most discovered phonological aspects in Nurhadi-Aldo meme was sound repetition or rhymes. Rhymes were typically used in the poetry with two lines (couplet) and mostly with four lines (quatrain). Followings were the memes using rhymes as the strategy. Firstly, the data number 44 "No Ninja, No Cinta, No Efyu, No I love U" (No ninja [a type of sport bike], No love, No Efyu [another kind of sport bike], No I love you] which used rhyme pattern AABB. Furthermore, the sound repetition -an or rhyme with AA pattern was also found in data number 63 "Ingat sarapan lebih baik dari pada harapan" (remembering breakfast is better than hopes). Sound repetition, which is similar to and used typically in verse creation strategy, aimed to make the meme legible and audible in a more beautiful way.

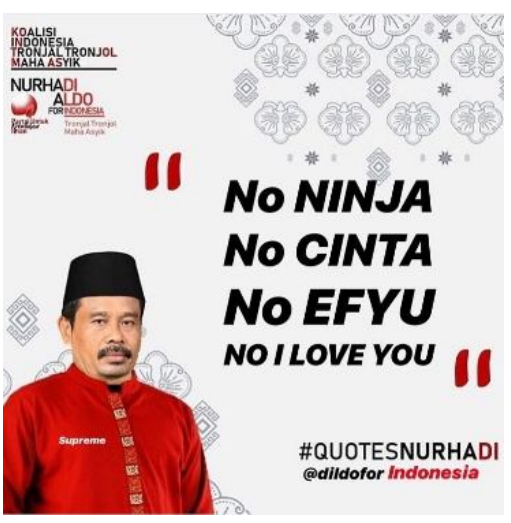

Figure 4. Data 44

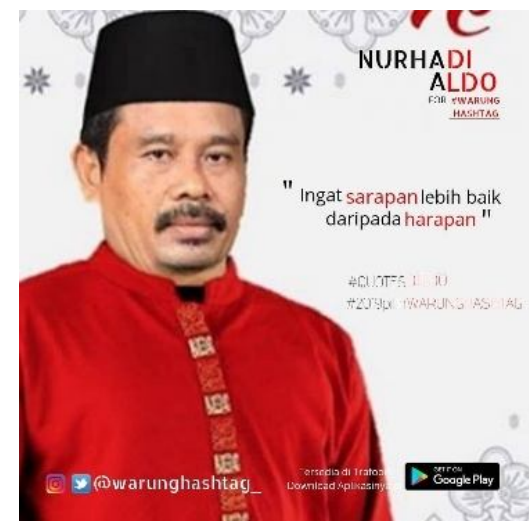

Figure 5. Data 63

\section{Semantic aspects supporting Dildo meme wittiness}

Besides phonological aspects, semantic aspects also played a significant role in supporting the level of wittiness of Dildo political memes. The followings were semantic aspects found: proverb, abbreviations, polysemy, metaphor, and syllogism. 
A proverb is a group of words or sentences with special intentions and moaning about the state or the behavior of someone and its life. The proverb also knows as adage functioning as providing implicit meaning for the readers or the listeners. In the Dildo political memes' making process, some memes were found using puns based on many proverbs, as shown by data number 24 "orang miskin dilarang miskin" (the poor must not poor) which a pun from the proverb "orang miskin dilarang sakit" (the poor must not get sick). Moreover, data number 37 "jangan mengulangi kesalahan yang sama karena kesalahan lain masih ada" (do not repeat the same mistake since the other mistakes do still exist) was a pun from proverb "jangan jatuh kedalam lubang yang sama dua kali" (do not fall into the same hole twice) meaning do not repeat your mistakes again and again.

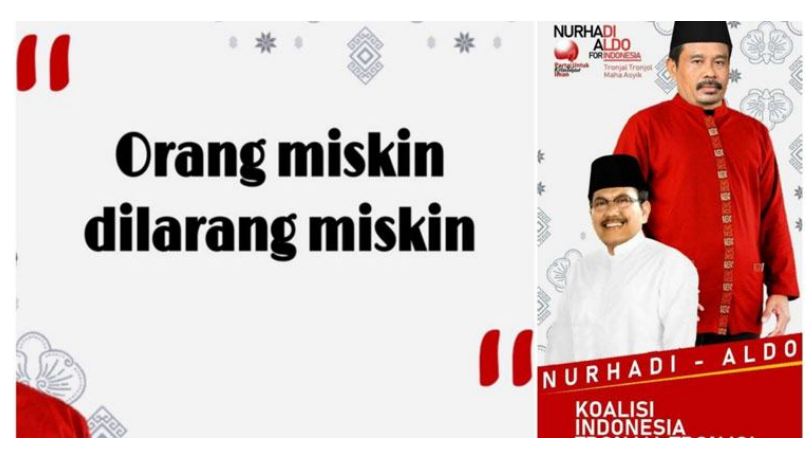

Figure 6. Data 24

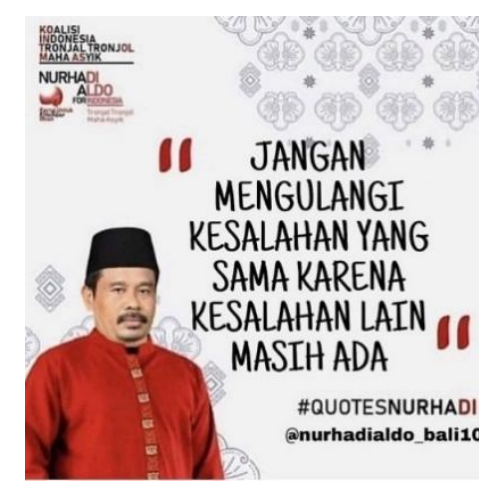

Figure 7. Data 25

\section{Abbreviation}

Abbreviation and acronym are short forms of words or groups of words. While the abridgment of acronym can be pronounced as syllables, it is not the case for abbreviations. The followings were some Dildo memes which used abbreviations and acronym. Firstly, in data number 22, "saya sedang bersama PELAKOR (penyanyi lagu korea)" (I am with Pelakor [Korean singers]). Initially, PELAKOR was the acronym for women who love to take over others' husbands, but it was punned into Korean singers. Another striking abbreviation is from data number 40 saying that "kalau saya menjadi presiden, Pekan Olahraga Nasional (PON) akan saya ubah namanya menjadi Pekan Olah Raga Nasional (PORN) (If I were a president, National Sport Week [PON] will be changed its name by me into National Sport Week [PORN]) (the changes were subtle and cannot equally be translated to English because sports in Bahasa can be split into two meaningful syllables while it is not the case in English. Sports cannot be divided into spo and rt and remain meaningful). The meme used acronym and intended to change PON into PORN in naming national sports week. The strategy succeeds in giving humorous taste in the meme.

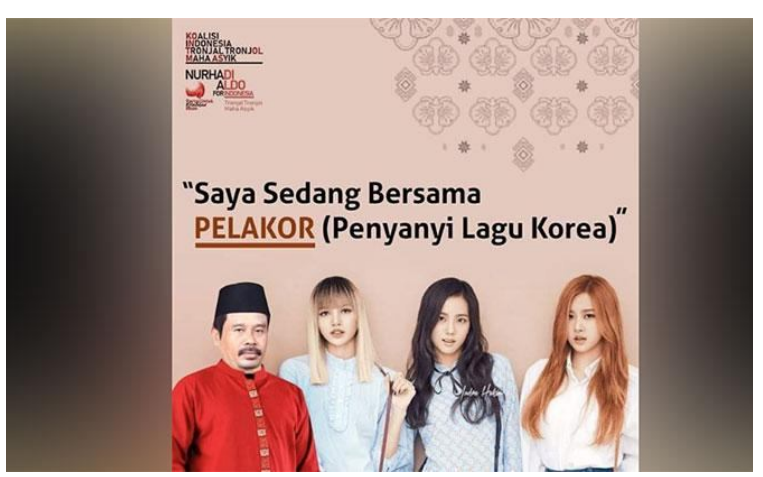

Figure 8. Data 26

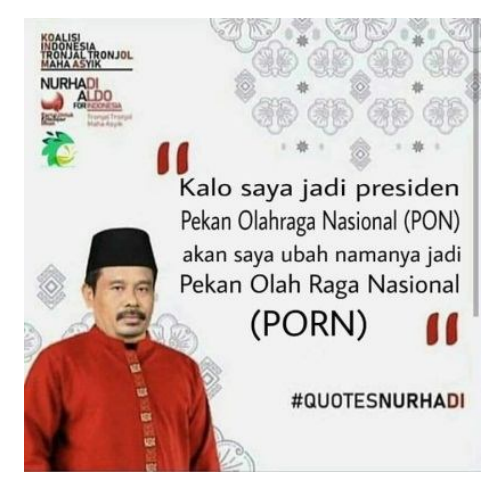

Figure 9. Data 40 
Semantic aspects which use polysemy take advantage of ambiguity as its fundamental element in making humorous sense in Dildo Meme. The ambiguity is demonstrated with uses of words having double meaning or primary and secondary meanings. It is well-illustrated by the data number 46 "IPK and kecil? Coba di-zoom" (is your GPA small? Try to zoom it in) (In Bahasa Indonesia, rather than low, GPA is customarily mentioned with small). Small here was ambiguous or had double meaning because primarily small meant not big and used to show size. However, in this meme, GPA was equated with size so that it can be zoomed in if it was wished to make it big. Of course, because GPA is not size, the most viable way to improve GPA is by studying properly.

Similarly, data number 70 also displays double meanings in word exploring on the expression "Tak ada gunanya mengarungi lautan, lebih baik mengarungi beras" (There is no benefit in exploring oceans, exploring [packing] rice is way better). It is clear that regardless of the forms and pronunciations, which werethe same, exploring here had two different meanings. While exploring oceans means sailing or wading a sea, exploring rice means packing amounts of rice to a sack.

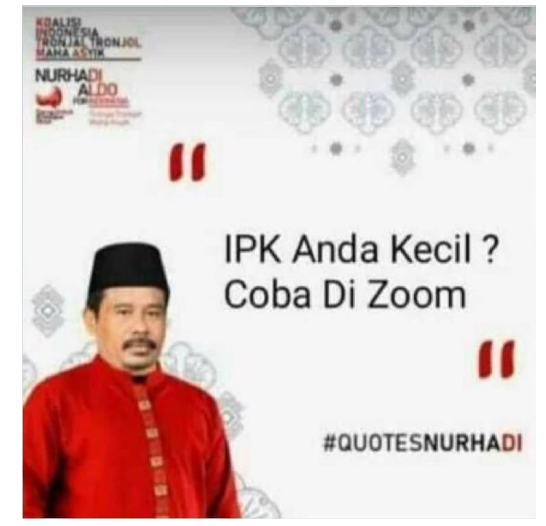

Figure 10. Data 46

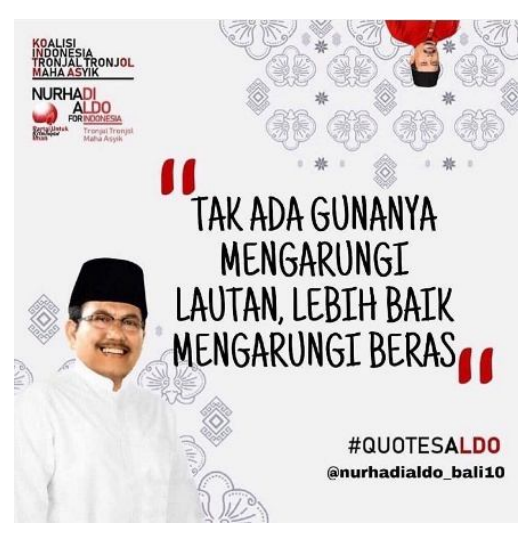

Figure 11. Data 70

\section{Metaphor}

Metaphor is one of the figures of speeches or rhetorical figures in Bahasa Indonesia which compare unequally and implicitly one thing with another. Meaning containing in the metaphor is not the ordinary meaning; instead, it is a form of simile founded on similarity and comparison. Metaphor in Dildo meme can be found in the data number 46 "Tanah kita sungguh subur, tanam bibit ghibah, yang tumbuh buah bibir" (Our soil is clearly fertile, planting seeds of gossip, the fruits are rumors). This expression juxtaposed two things unequally, seeds of gossips and with plant seeds which can flourish. This expression also implies an insinuation that Indonesian people are still keen on gossiping other people with the phrase "the fruits are rumors."

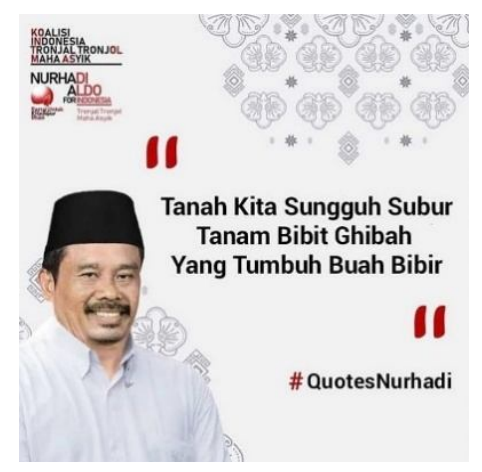

Figure 12. Data 46

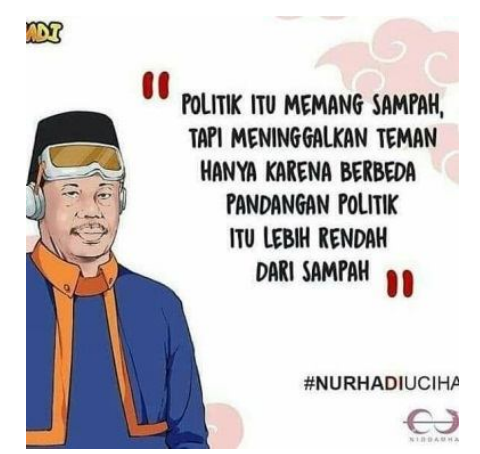

Figure 13. Data 56 
In the data number 56 "Politik itu memang sampah, tetapi meninggalkan teman hanya karena berbeda pandangan itu lebih rendah dari sampah" (Politic is admittedly trash, but leaving friends for political perspectives only is dirtier than trash) compared two common terms, politics and trash. In the meme, containing implication or intended meaning that one should not break his friendship for political perspective only.

\section{Syllogism}

The last semantic strategy found in Dildo meme was Syllogism. A syllogism is an attempt, way of thinking, or concluding process consisting of major and minor premise and conclusion. In the meme making process, usually, the conclusion should be unpredictable for producing humorous sense. This quality was found in the data number 60 "Jika Anda pemalas, malaslah setiap hari, sehingga anda jadi pemalas yang rajin" (If you are a sluggard, be lazy every day so that you will be a diligent sluggard). The humorous discourse in this meme wasthat if you are a sluggard (major premise), be lazy every day (minor premise), you will be a diligent sluggard (conclusion). It is a witty joke because it deviates from the maxim of relevance by making an irrelevant conclusion which is different from common value hold in reality.

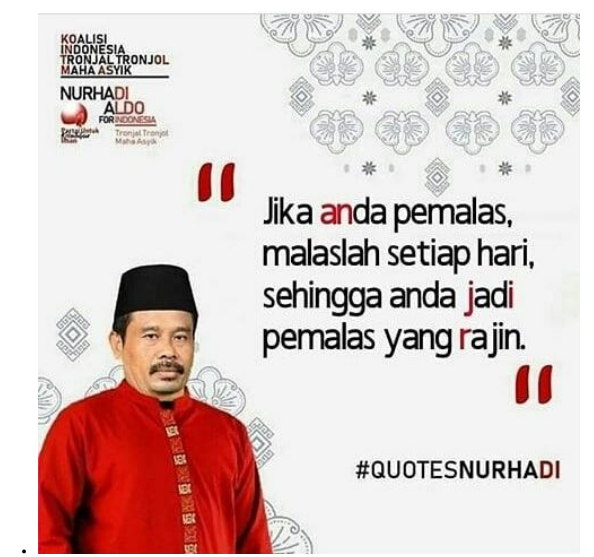

Figure 14. Data 60

\section{CONCLUSION}

All things considered, especially regarding the roles of linguistic aspect in the Nurhadi-Aldo memes' making process, a conclusion can be made. Phonological and semantic elements played essential roles in compounding humorous discourse in the memes. The phonological aspects were mostly found in the homonym and rhymes while the semantic aspect was often discovered in some strategy, ranging from proverb, abbreviation, polysemy, metaphor, and syllogism.

\section{REFERENCES}

Wijana, I Dewa Putu (2003) Wacana Dagadu, Permainan Bahasa dan Ilmu Bahasa. Pidato Pengukuhan Jabatan Guru Besar di Fakultas Ilmu Budaya, Universitas Gadjah Mada. Yogyakarta

Rohmadi, M (2010), Strategi Penciptaan Humor dengan Pemanfaatan Aspek-aspek Kebahasaan. Humaniora, Volume 22 No.3 pp 285-298.

Mahadian, Adi B, (2014), Humor Politik sebagai Sarana Demokratisasi Indonesia. Jurnal ISKI (IkatanSarjanaKomunikasi Indonesia) Jakarta.

Listiyorini, Ari, (2017), Wacana Humor dalam Meme di Media Online Sebagai Potret Kehidupan Sebagian Masyarakat Indonesia. LITERA, Volume 16, No.1.

Widyaningrum, AY. Hartiana, Theresia (2017). Wacana Politisi Perempuan dalam Meme. Jurnal Komunikatif, Vol 6. No.2 
8

Ilham, M, (2017), Presentasi Budaya Populer Meme Comic Indonesia (AnalisisSemiotika Meme dalam Fanpage Meme Comic Indonesia). Thesis in Departemen Ilmu Komunikasi Fakultas Ilmu Sosial dan Ilmu Politik. Universitas Hasanuddin.

Soeparno, (2003), Dasar-Dasar Linguistik Umum, Yogyakarta, Tiara Wacana

Chaer, A. (2009), Fonologi Bahasa Indonesia, Jakarta, RinekaCipta

Sumber online :

https://www.instagram.com/nurhadi_aldo/ 